NOTE

\title{
First record of nest building, spawning and sexual dimorphism in the threatened Cowichan Lake lamprey Entosphenus macrostomus
}

\author{
Joy Wade ${ }^{1, *}$, Lindsay Dealy $^{2}$, Sean MacConnachie $^{2}$ \\ ${ }^{1}$ Fundy Aqua Services, Nanoose Bay, British Columbia V9P 9B3, Canada \\ ${ }^{2}$ Fisheries and Oceans Canada, Nanaimo, British Columbia V9T 6N7, Canada
}

\begin{abstract}
The Cowichan Lake lamprey Entosphenus macrostomus is a parasitic freshwater fish endemic to Cowichan, Mesachie and Bear lakes in British Columbia, Canada. Its restricted distribution and inherent vulnerability to localized threats were principal factors resulting in this species being listed as 'threatened' under Canada's Species at Risk Act. This study documents the first report of nest building, spawning and sexual dimorphism in E. macrostomus. Preliminary data such as spawning locations and nest size will inform the management and protection of this species and its habitat as a Species at Risk, as well as future research.
\end{abstract}

KEY WORDS: Lamprey $\cdot$ Spawning $\cdot$ Nest building $\cdot$ Habitat $\cdot$ Conservation $\cdot$ British Columbia

\section{INTRODUCTION}

Cowichan Lake lamprey Entosphenus macrostomus are found only in Mesachie, Bear and Cowichan lakes on Vancouver Island, British Columbia, Canada (Fig. 1). The species was first described in 1982 as Lampetra macrostoma (Beamish 1982) and was listed in 2003 as 'threatened' under Canada's Species at Risk Act. Listing was partly based on its restricted distribution and inherent vulnerability to localized threats, such as habitat alteration.

Little is known of the general biology, behaviour and spawning habitat of Cowichan Lake lamprey. The species is considered Endangered by the IUCN (2017). Spawning has been reported from May to the end of July, with peak spawning in June (Beamish \& Wade 2008). Mature lamprey have only been observed in 2 locations, a tributary to Mesachie Lake and the mouth of Robertson River in

\footnotetext{
*Corresponding author: joywadefundyaqua@gmail.com
}

Bear Lake (Beamish 1982, Beamish \& Wade 2008). Presence of mature lamprey has not been confirmed in Cowichan Lake, although observations of very small ammocoetes $(<50 \mathrm{~mm})$ suggested potential spawning locations (Wade \& MacConnachie 2016). E. macrostomus have not been observed building nests, spawning or holding in spawning areas (Beamish \& Wade 2008).

Our goals were to confirm the presence of mature Cowichan Lake lamprey in tributaries of Cowichan and Bear lakes and to observe and increase knowledge of nest building and spawning by this species. This study addresses several items in the recovery strategy (DFO 2007) and informs the identification of critical habitat (MacConnachie \& Wade 2016). For conservation concerns, spawning areas must be identified to inform decisions about water extraction from the Cowichan and Bear lake system during typical and abnormal precipitation years.

๑ J J. Wade and Fisheries and Oceans Canada 2018. Open Access under Creative Commons by Attribution Licence. Use, distribution and reproduction are unrestricted. Authors and original publication must be credited.

Publisher: Inter-Research · www.int-res.com 


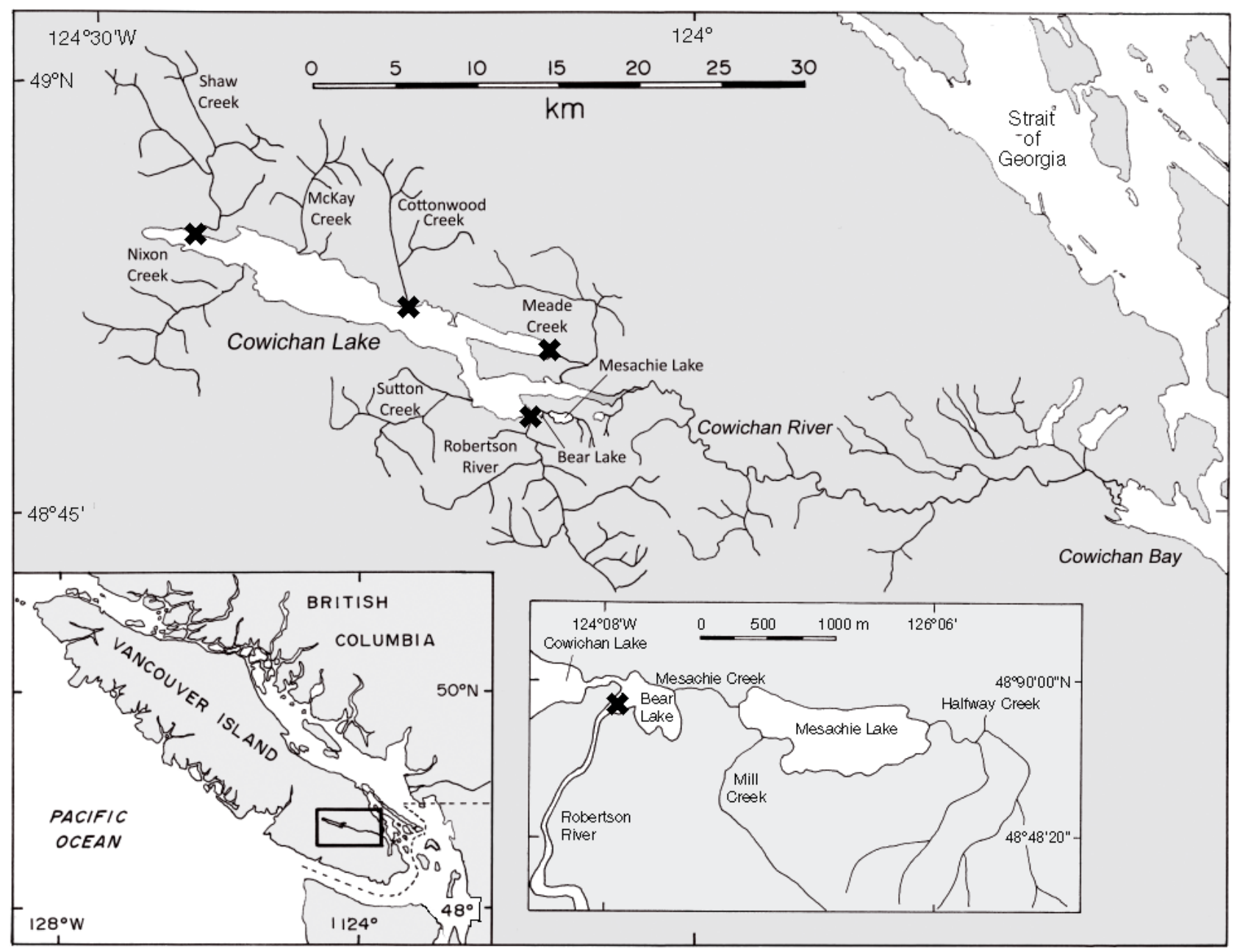

Fig. 1. Global range of Entosphenus macrostomus including Cowichan, Mesachie and Bear lakes on Vancouver Island, British Columbia, Canada. The 4 trapping locations in 2017 are indicated by ' $\mathbf{X}$ '. Enlargement of Bear Lake and the trapping location on Robertson River $(\mathbf{x})$ is shown in the right inset. Dotted line (bottom left inset) delineates the Canadian-US border

\section{MATERIALS AND METHODS}

\section{Trapping}

To determine presence of Entosphenus macrostomus in spawning condition, trap lines consisting of minnow traps placed at the base of a mesh 'weir' were installed as described by Beamish \& Wade (2008) at 4 locations: 1 tributary of Bear Lake and 3 tributaries of Cowichan Lake (Table 1). Trap lines were placed in the alluvial fan of the creeks and the river (Table 1) parallel to flow.

Traps were deployed on 12 June 2017 and removed on 30 June 2017 (Table 1). Water depth was measured at the ends and the middle of the trap line at trap installation and removal (Table 1). All trap locations were referenced using a handheld GPS (Garmin GPSmap 60Cx).

\section{Sampling}

Traps were emptied daily, and captured lamprey were placed in a 101 bucket filled with water taken directly from the trapping site. On-shore, each lamprey was anaesthetized with tricaine methanesulphonate (100-125 ppm), sex was checked, and total length was measured to the nearest millimetre using a standard measuring board. As sexual dimorphism has not been described for E. macrostomus, individuals were examined visually for secondary sexual characteristics using the qualitative description in Kott et al. (1988), based on Vladykov (1949), Smith et al. (1968) and Hardisty \& Potter (1971).

Fins were clipped as described for ammocoetes by Wade \& MacConnachie (2016). After sampling, fish were placed in a bucket filled with water, allowed to recover from anaesthesia (estimated time was ap- 
Table 1. Summary of locations of lamprey trap lines in Bear and Cowichan lakes, British Columbia, Canada. Water depth was measured at the ends and the middle of the trap line

\begin{tabular}{|c|c|c|c|c|c|c|c|c|c|c|}
\hline Location & $\begin{array}{l}\text { Descrip- } \\
\text { tion }\end{array}$ & $\begin{array}{c}\text { Date } \\
\text { installed } \\
(2017)\end{array}$ & $\begin{array}{l}\text { Date } \\
\text { removed } \\
(2017)\end{array}$ & $\begin{array}{l}\text { Days } \\
\text { fishing }\end{array}$ & $\begin{array}{l}\text { Latitude } \\
\qquad\left({ }^{\circ} \mathrm{N}\right)\end{array}$ & $\begin{array}{l}\text { Longitude } \\
\qquad\left({ }^{\circ} \mathrm{W}\right)\end{array}$ & $\begin{array}{l}\text { Minnow } \\
\text { traps (n) }\end{array}$ & $\begin{array}{l}\text { Length } \\
\text { of trap } \\
\text { line } \\
(\mathrm{cm})\end{array}$ & $\begin{array}{l}\text { Water } \\
\text { depth } \\
\text { at install } \\
(\mathrm{cm})\end{array}$ & $\begin{array}{l}\text { Water } \\
\text { depth at } \\
\text { removal } \\
(\mathrm{cm})\end{array}$ \\
\hline Robertson River & $\begin{array}{l}\text { Mid-river } \\
\text { Side river }\end{array}$ & $\begin{array}{l}12 \text { June } \\
12 \text { June }\end{array}$ & $\begin{array}{l}30 \text { June } \\
30 \text { June }\end{array}$ & $\begin{array}{l}18 \\
18\end{array}$ & $\begin{array}{l}48^{\circ} 48^{\prime} 55.5^{\prime \prime} \\
48^{\circ} 48^{\prime} 54.4^{\prime \prime}\end{array}$ & $\begin{array}{l}124^{\circ} 07^{\prime} 47.9^{\prime \prime} \\
124^{\circ} 07^{\prime} 48.4^{\prime \prime}\end{array}$ & $\begin{array}{l}9 \\
6\end{array}$ & $\begin{array}{l}320 \\
420\end{array}$ & $\begin{array}{l}50,57,60 \\
70,62,79\end{array}$ & $\begin{array}{l}50,56,62 \\
72,77,81\end{array}$ \\
\hline Cottonwood Creek & Mid-creek & $\begin{array}{l}12 \text { June } \\
20 \text { June }\end{array}$ & $\begin{array}{l}16 \text { June } \\
\text { 30 June }\end{array}$ & $\begin{array}{c}4 \\
10\end{array}$ & $\begin{array}{l}48^{\circ} 52^{\prime} 28.1^{\prime \prime} \\
48^{\circ} 52^{\prime} 28.4^{\prime \prime}\end{array}$ & $\begin{array}{l}124^{\circ} 14^{\prime} 11.4^{\prime \prime} \\
124^{\circ} 14^{\prime} 11.6^{\prime \prime}\end{array}$ & $\begin{array}{l}8 \\
7\end{array}$ & $\begin{array}{l}440 \\
440\end{array}$ & $\begin{array}{l}56,56,60 \\
65,70,68\end{array}$ & $\begin{array}{c}\text { Too fast to measure } \\
68,65,67\end{array}$ \\
\hline Meade Creek N & Mid-creek & 16 June & 30 June & 14 & $48^{\circ} 50^{\prime} 41.7^{\prime \prime}$ & $124^{\circ} 07^{\prime} 04.1^{\prime \prime}$ & 6 & 360 & $22,24,20$ & $22,24,20$ \\
\hline Shaw Creek & $\begin{array}{l}\text { Mid-creek } \\
\text { Side creek }\end{array}$ & $\begin{array}{l}12 \text { June } \\
18 \text { June } \\
12 \text { June }\end{array}$ & $\begin{array}{l}16 \text { June } \\
30 \text { June } \\
30 \text { June }\end{array}$ & $\begin{array}{c}4 \\
12 \\
18\end{array}$ & $\begin{array}{l}48^{\circ} 55^{\prime} 06.3^{\prime \prime} \\
48^{\circ} 55^{\prime} 06.4^{\prime \prime} \\
48^{\circ} 55^{\prime} 05.2^{\prime \prime}\end{array}$ & $\begin{array}{l}124^{\circ} 24^{\prime} 35.7^{\prime \prime} \\
124^{\circ} 24^{\prime} 36.0^{\prime \prime} \\
124^{\circ} 24^{\prime} 37.0^{\prime \prime}\end{array}$ & $\begin{array}{l}7 \\
5 \\
5\end{array}$ & $\begin{array}{l}340 \\
340 \\
340\end{array}$ & $\begin{array}{l}68,74,68 \\
50,39,37 \\
33,30,50\end{array}$ & $\begin{array}{c}\text { Too fast to measure } \\
53,43,46 \\
39,37,55\end{array}$ \\
\hline
\end{tabular}

proximately $1 \mathrm{~min})$, and returned to the wild. All methods for handling Cowichan Lake lamprey were in accordance with the scientific permit issued by Fisheries and Oceans Canada.

\section{River/creek surveys}

Streams were walked to determine how far up the creeks and the river mature lamprey could be found and to ascertain whether they were building nests, spawning or just swimming. Surveys were conducted from the confluence of Cottonwood Creek, Shaw Creek and Robertson River and their corresponding lake, upstream to defined end points (Table 2). Survey distance was measured by inputting the start and end points into the World Imagery Basemap in ArcMap 10.4.1; using the Go To XY tool, the survey path was drawn and quantified with the Measure tool. The time at which surveys began varied because spawning time was unknown. Because water depth did not exceed $0.9 \mathrm{~m}$, lamprey could be viewed if present. After an initial search at the confluence of each tributary along 2 horizontal transects, the entire wetted width was visible with 1 pass up the middle of the creek or river. Survey effort was concentrated at Robertson River (Table 2), the most successful trapping location.

Table 2. Summary of Entosphenus macrostomus surveys made in Robertson River and Cottonwood and Shaw creeks. Survey times and distances are approximations. ToD: approximate time of day

\begin{tabular}{|c|c|c|c|c|c|c|}
\hline & \multicolumn{2}{|c|}{ Robertson River } & \multicolumn{2}{|c|}{ Cottonwood Creek } & \multicolumn{2}{|c|}{ Shaw Creek } \\
\hline Start & $48^{\circ} 48^{\prime} 55.5^{\prime}$ & $\mathrm{N}, 124^{\circ} 07^{\prime} 47.9^{\prime \prime} \mathrm{W}$ & $48^{\circ} 52^{\prime} 27.7^{\prime \prime}$ & I, $124^{\circ} 14^{\prime} 11.3^{\prime \prime} \mathrm{W}$ & $48^{\circ} 55^{\prime} 06.3$ & N, $124^{\circ} 24^{\prime} 36.3^{\prime \prime} \mathrm{W}$ \\
\hline End & $48^{\circ} 48^{\prime} 48.0$ & $\mathrm{~N}, 124^{\circ} 08^{\prime} 04.1^{\prime \prime} \mathrm{W}$ & $48^{\circ} 52^{\prime} 39.5^{\prime \prime}$ & I, $124^{\circ} 14^{\prime} 15.1^{\prime \prime} \mathrm{W}$ & $48^{\circ} 55^{\prime} 14.0$ & $\mathrm{~N}, 124^{\circ} 24^{\prime} 26.0^{\prime \prime} \mathrm{W}$ \\
\hline Survey time (min) & & 22 & & 25 & & 25 \\
\hline Distance $(\mathrm{m})$ & & 650 & & 670 & & 770 \\
\hline Date & ToD (h) & No. observers & ToD (h) & No. observers & ToD (h) & No. observers \\
\hline 17 June & $12: 00$ & 1 & & & & \\
\hline 18 June & $13: 00$ & 1 & & & & \\
\hline 22 June & $16: 15$ & 1 & & & & \\
\hline 23 June & $11: 00$ & 1 & & & & \\
\hline 24 June & $11: 00$ & 1 & & & & \\
\hline 25 June & $12: 00$ & 1 & & & & \\
\hline 26 June & $11: 30$ & 1 & & & & \\
\hline 27 June & $10: 30$ & 1 & & & & \\
\hline 29 June & 09:30 & 1 & & & & \\
\hline 7 July & & & $10: 00$ & 2 & 08:30 & 2 \\
\hline 14 July & $12: 30$ & 1 & $10: 30$ & 1 & $09: 15$ & 1 \\
\hline 15 July & $11: 00$ & 2 & $12: 15$ & 2 & $14: 20$ & 2 \\
\hline 16 July & $10: 10$ & 1 & $13: 00$ & 1 & $11: 45$ & 1 \\
\hline
\end{tabular}


Depressions in the substrate and lamprey nests were difficult to differentiate, so only nests in which spawning was observed were documented. Nest photographs were taken at the time of spawning. To minimize nest disturbance, 1 nest, site 1, was selected for rock measurement. The day after spawning, a hard copy of the nest photograph was used in the field to identify specific rocks to be measured, as well as width and length of the nest. Rocks were numbered on the photograph and measured in situ. Because lamprey spawned in and around small pebbles in the middle of nests, pebbles were not measured to avoid harm to developing embryos.

\section{RESULTS}

\section{Trapping and sampling}

From 14 to 30 June 2017, we captured 31 lamprey, of which 3 were recaptured. Of the 28 unique lamprey captured, 19 were male (mean \pm SD length: $193.7 \pm 13.4 \mathrm{~mm}$ ) and 9 were female $(182.0 \pm 11.0 \mathrm{~mm}$; Table 3).

Lamprey were only captured in Cottonwood Creek and Robertson River. Two fish were captured at Cottonwood Creek (14 and 21 June 2017). Most lamprey were captured at the end of June (Fig. 2). The highest daily capture was 6 individuals on 27 June. From 15 to 21 June, no lamprey were caught. A major storm event on 15 and 16 June deposited $30 \mathrm{~mm}$ of rain. During the storm and for several days after, water flow in the creeks and rivers was relatively high, but flow rates were not measured. One trap line at Shaw Creek and the trap line at Cottonwood Creek were removed for several days because of this high flow to prevent trap damage or loss.

Sex was consistent with the description by Kott et al. (1988) in that males had an elongate urogenital papilla, swollen cloaca and downturned tail. Females had an elongate urogenital papilla, a post-anal fold or keel posterior to the cloaca and a sharp upturned tail (Fig. 3).
Table 3. Summary of Entosphenus macrostomus catches and length in Cowichan and Bear lakes, 2017

\begin{tabular}{|lccccc|}
\hline & \multicolumn{4}{c}{ Length $(\mathrm{mm})$} & \multirow{2}{*}{ No. of } \\
\cline { 2 - 5 } & Average & Max. & Min. & SD & fish \\
\hline Male & 193.7 & 225.0 & 175.0 & 13.4 & 19 \\
Female & 182.0 & 194.0 & 168.0 & 11.0 & 9 \\
All lamprey & 189.9 & 225.0 & 168.0 & 13.6 & 28 \\
& & & & & \\
\hline
\end{tabular}

\section{River/creek surveys}

No lamprey were observed spawning or building nests during river or creek surveys. On 14 July, 1 lamprey was observed swimming and taking shelter under woody debris at the confluence of Robertson River and Bear Lake near the location of the mid-river trap line. Colouration of this fish was not normal in that the anterior of the fish was light beige and the posterior was typical dark green/brown. This fish may have been post-spawn and dying.

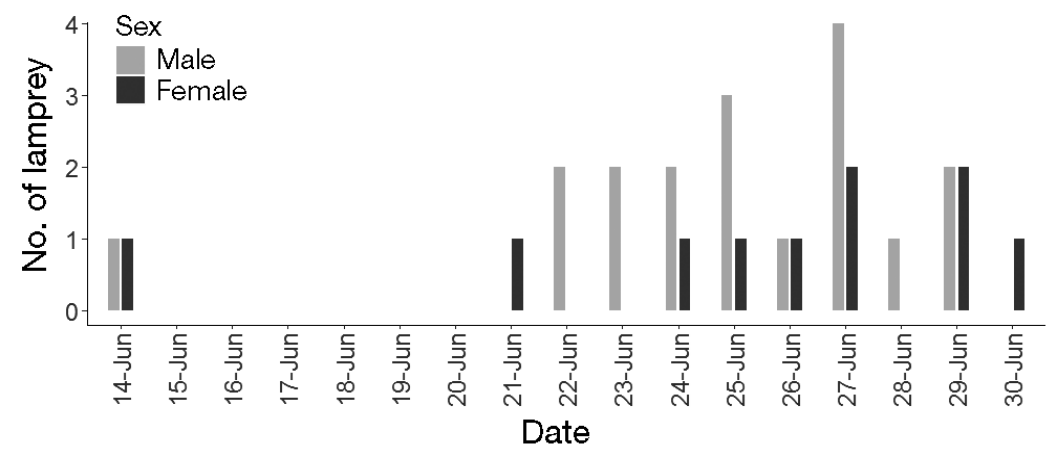

Fig. 2. Daily captures of Entosphenus macrostomus from all 4 trapping locations in 2017
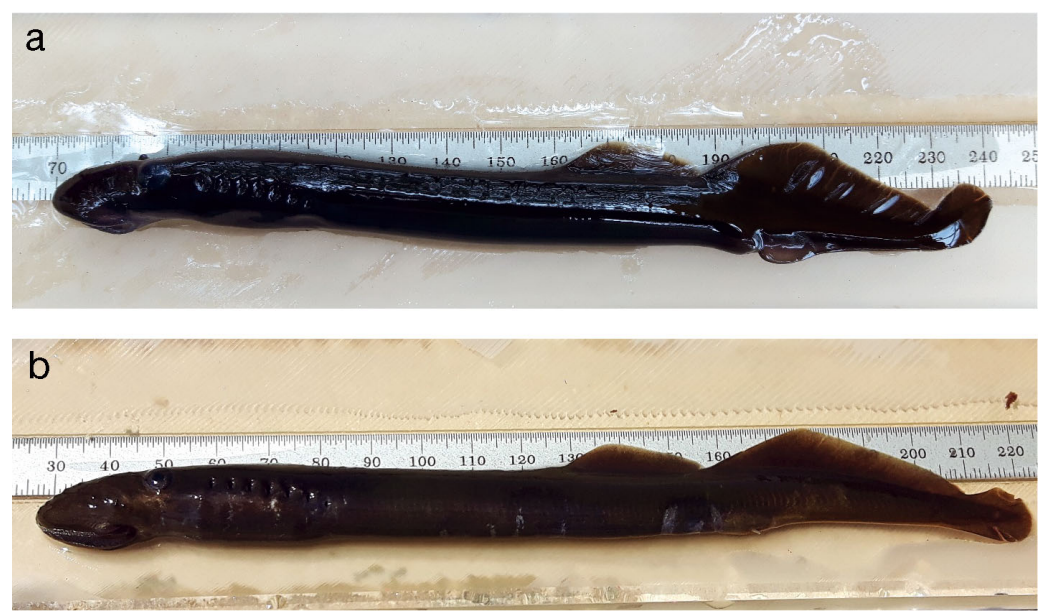

Fig. 3. Entosphenus macrostomus (a) female and (b) male 
Spawning was observed on 3 separate occasions and nest building on 1 occasion at the Robertson River location when checking traps. These sightings were not during river surveys. Nest building by 1 male lamprey was observed near the midriver trap line $\left(45^{\circ} 48^{\prime} 54.6^{\prime \prime} \mathrm{N}, 124^{\circ}\right.$ $\left.07^{\prime} 48.5^{\prime \prime} \mathrm{W}\right)$ at the mouth of Robertson River on 23 June 2017. Both during nest building and spawning, lamprey were observed moving rocks much larger (estimated minimum 1/3 larger) than their head diameter. Nest building was observed at 10:00 h on 23 June and took longer than 15 min (observation time).

Spawning was observed on 3 separate occasions at the mouth of Robertson River (Table 4). Spawning on 2 nests took place near the site where nest building occurred and the mid-river trap line (Fig. 4). The second spawning location was near the end of the alluvial fan (Fig. 4). Spawning occurred in water ranging between 42 and $65 \mathrm{~cm}$ deep. The total duration of spawning was unknown, but was observed for 15 to 25 min (Table 4).

The overall nest size at site 1 was $55 \times 23 \mathrm{~cm}$. Not all rocks measured were seen to be moved by the lamprey, but a sub-sample was measured to represent a range of sizes that formed the nest (Table 5).
Table 4. Summary of Entosphenus macrostomus spawning sites at the mouth of Robertson River. Length of obs.: estimated length of spawning observation

\begin{tabular}{|ccccccc|}
\hline & $\begin{array}{c}\text { Date } \\
(2017)\end{array}$ & $\begin{array}{c}\text { Latitude } \\
\left({ }^{\circ} \mathrm{N}\right)\end{array}$ & $\begin{array}{c}\text { Longitude } \\
\left({ }^{\circ} \mathrm{W}\right)\end{array}$ & $\begin{array}{c}\text { Length of } \\
\text { obs. } \\
(\mathrm{min})\end{array}$ & $\begin{array}{c}\text { No. } \\
\text { lamprey }\end{array}$ & $\begin{array}{c}\text { Water } \\
\text { depth } \\
(\mathrm{cm})\end{array}$ \\
\hline Site 1 & 23 June & $48^{\circ} 48^{\prime} 55.1^{\prime \prime}$ & $124^{\circ} 07^{\prime} 48.9^{\prime \prime}$ & $>15$ & 2 & 42.0 \\
Site 2 & 27 June & $48^{\circ} 48^{\prime} 54.8^{\prime \prime}$ & $124^{\circ} 07^{\prime} 44.4^{\prime \prime}$ & $>25$ & 4 & 65.0 \\
Site 3 & 29 June & $48^{\circ} 48^{\prime} 54.8^{\prime \prime}$ & $124^{\circ} 07^{\prime} 48.9^{\prime \prime}$ & $>15$ & 2 & 58.0 \\
\hline
\end{tabular}

Both males and females moved rocks during spawning, and did not appear to be 'covering' fertilized eggs, but rather, moving rocks, sometimes to the periphery of the nest. Males and females both moved or fanned small pebbles (e.g. substrate under the lamprey in Fig. 5) with their bodies. During mating, males moved on top of the female while clutching the top of the female's head with their oral disc. After some re-positioning, both males and females moved their bodies side to side and eventually the male coiled his lower body around the female's middle and squeezed, during which both gyrated. This occurred several times over the spawning event, sometimes with a few minutes between events in which they either remained inactive or swam around the nest individually. This activity was observed at each of the 3 nests. At 1 nest, after spawning, the male left the nest last. Lamprey had not finished spawning at sites 2 and 3 when observations ended.

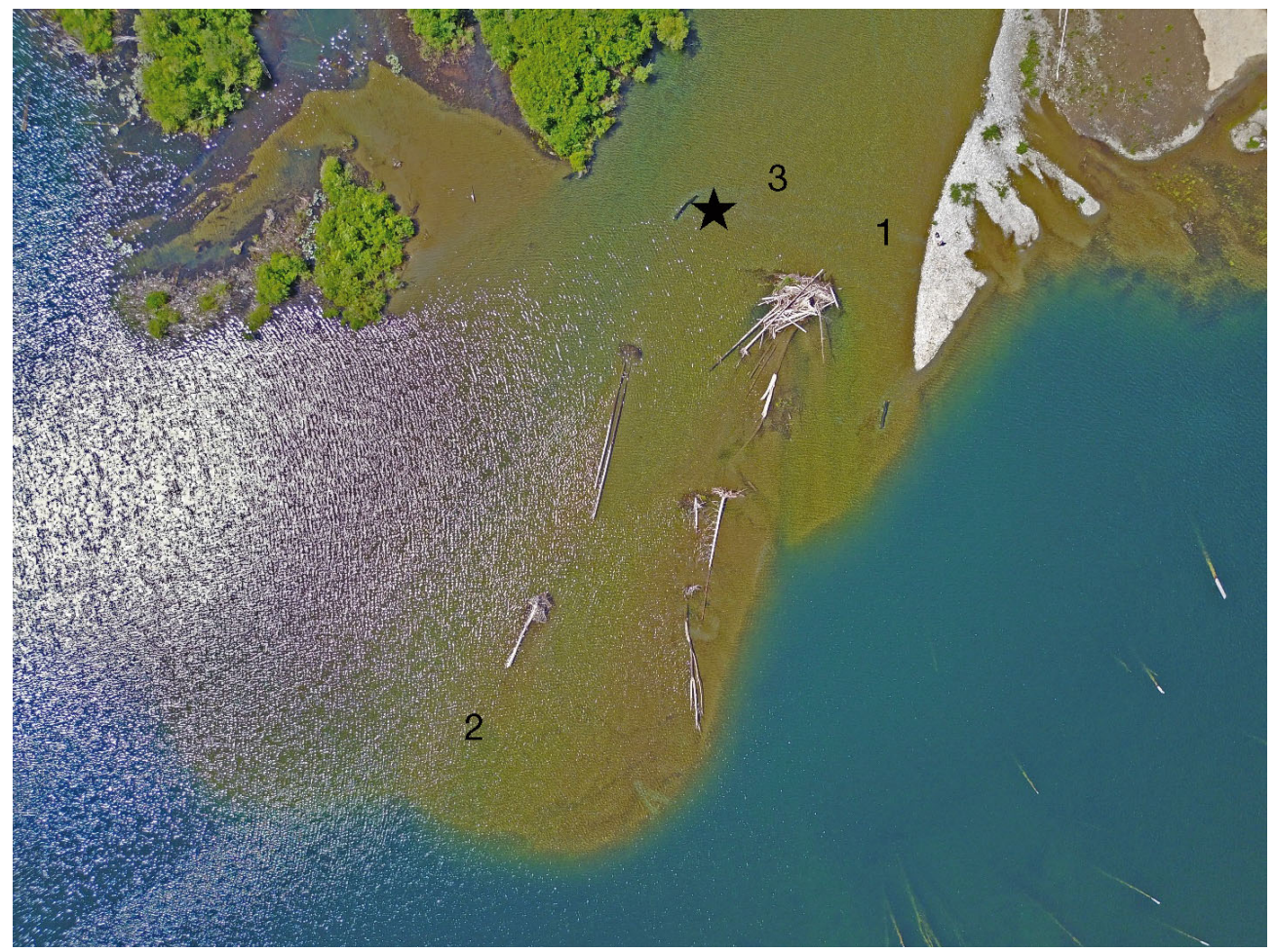

Fig. 4. Locations of spawning events (1-3) and nest building (star) in the alluvial fan at the confluence of Robertson River and Bear Lake, British Columbia, Canada. Midriver trap line is visible as a black line to the left of the star; side river trap line is the black line visible at the tip of the white sandbar 
Table 5. Rock measurements from spawning nest 1 . Rock numbers correspond to those labelled in Fig. 5

\begin{tabular}{|ccc|}
\hline Rock & Length $(\mathrm{cm})$ & Width $(\mathrm{cm})$ \\
\hline 1 & 7.4 & 5.5 \\
2 & 6.4 & 3.3 \\
3 & 5.2 & 4.2 \\
4 & 4.8 & 3.5 \\
5 & 4.8 & 3.4 \\
6 & 6.1 & 3.3 \\
7 & 4.0 & 4.2 \\
8 & 3.0 & 3.4 \\
9 & 2.5 & 2.0 \\
10 & 3.0 & 1.8 \\
11 & 1.0 & 1.4 \\
12 & 2.3 & 1.8 \\
13 & 1.1 & 2.0 \\
14 & 3.9 & 1.5 \\
15 & 5.8 & 4.5 \\
16 & 3.2 & 2.1 \\
17 & 5.4 & 3.1 \\
18 & 1.8 & 1.1 \\
19 & 5.4 & 3.1 \\
20 & 2.0 & 1.5 \\
\hline
\end{tabular}

Two lamprey (1 male, 1 female) spawned at 2 sites, while 4 lamprey spawned at another site (Table 4 ). At 1 site, water depth prevented us from determining the sex of the 4 lamprey, but we assumed that 2 males and 2 females spawned together as a group of 4 , as they also spawned in 2 pairs.

\section{DISCUSSION}

Preliminary data that we collected on the biology and behaviour of Cowichan Lake lamprey during the spawning season will be used to inform management of the species and future research. For example, knowing the time of year and where the lamprey are spawning will affect permit applications for habitat alteration such as dredging or habitat remediation. In addition, our study provided insights into spawning behaviour, including nest building and mating, which had not previously been documented for Entosphenus macrostomus. We also confirmed sexual dimorphism in E. macrostomus that is consistent with other lamprey species.

The relatively large size of rocks being moved during nest building and spawning was surprising. Previously, this species was believed to build nests only with pebbles smaller than $1 \mathrm{~cm}$ diameter (MacConnachie \& Wade 2016). We now know this was an underestimate, and can further refine substrate requirements for nest building and habitat protection guidelines.

For the first time, Cowichan Lake lamprey were confirmed to be present in spawning condition in a tributary to Cowichan Lake. Previously, mature lamprey were observed in a tributary of Mesachie Lake and at the mouth of Robertson River in Bear Lake

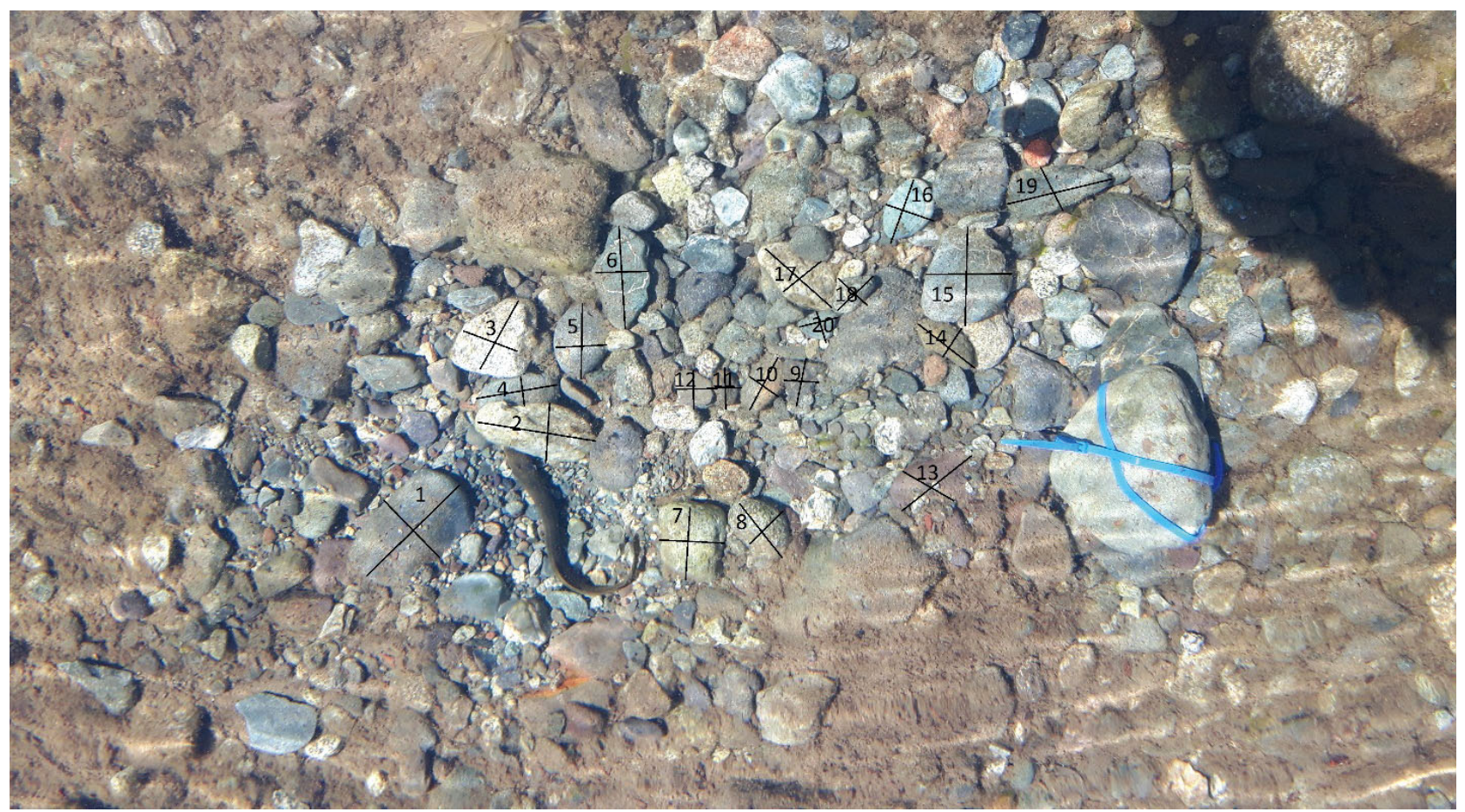

Fig. 5. Labelled rocks forming a nest at spawning site 1 at the confluence of Robertson River and Bear Lake. Mature lamprey can be seen between rocks labelled 1 and 2 
(Beamish 1982, Beamish \& Wade 2008). Therefore, we assume that the species spawns in the tributaries of Cowichan, Mesachie and Bear lakes, throughout its range. This information is important for protection of critical habitat for Cowichan Lake lamprey.

We were also able to determine that the lamprey spawn both as pairs and in groups in alluvial fans. Although lamprey were not observed farther up the tributaries from the alluvial fan, they may use this habitat. Spawning locations and habitat are particularly important in years of severe drought when ongoing water extraction from Cowichan and Bear lakes can leave little to no water in the alluvial fans for spawning (Wade et al. 2017).

Acknowledgements. Funding for this work was provided by both the Fisheries and Oceans Canada Species at Risk Program and British Columbia Ministry of Forests, Lands and Natural Resource Operations. We acknowledge the support of Greg Wilson, Craig Stephen, Vanessa Hodes and Lana Fitzpatrick.

\section{LITERATURE CITED}

Beamish RJ (1982) Lampetra macrostoma, a new species of freshwater parasitic lamprey from the west coast of Canada. Can J Fish Aquat Sci 39:736-747

Beamish RJ, Wade J (2008) Critical habitat and the conservation ecology of the freshwater parasitic lamprey,

Editorial responsibility: Uwe Krumme,

Rostock, Germany
Lampetra macrostoma. Can Field Nat 122:327-337

DFO (Department of Fisheries and Oceans Canada) (2007) Recovery strategy for Vancouver lamprey (Lampetra macrostoma) in Canada. Species at Risk Act Recovery Strategy Series. Fisheries and Oceans Canada, Ottawa, ON

Hardisty MW, Potter IC (1971) The general biology of adult lampreys. In: Hardisty MW, Potter IC (eds) The biology of lampreys, Vol 1. Academic Press, London, p 127-206

Kott E, Renaud CB, Vladykov VD (1988) The urogenital papilla in the Holarctic lamprey (Petromyzontidae). Environ Biol Fishes 23:37-43

MacConnachie SEM, Wade J (2016) Information in support of the identification of critical habitat for the Cowichan (Vancouver) lamprey (Entosphenus macrostomus). Res Doc 2016/109. DFO Canadian Science Advisory Secretariat, Ottawa, ON

* Smith AJ, Howell JH, Piavis GW (1968) Comparative embryology of five species of lampreys of the upper Great Lakes. Copeia 1968:461-469

Smith K (2017) Entosphenus macrostomas. The IUCN Red List of Threatened Species 2017:e.T11208A81468224. http://dx.doi.org/10.2305/IUCN.UK.2017-3.RLTS.T11208 A81468224.en (accessed 27 Dec 2017)

Vladykov VD (1949) Quebec lampreys. 1. List of species and their economic importance. Contr Dép Pêch Québec 26

Wade J, MacConnachie S (2016) Cowichan Lake lamprey (Entosphenus macrostomus) ammocoete habitat survey 2012. Can Manuscr Rep Fish Aquat Sci 3088

Wade J, Lovestrom N, MacConnachie S (2017) Observed reductions in spawning and rearing habitat availability for Cowichan lamprey (Entosphenus macrostomus) during drought conditions. Can Data Rep Fish Aquat Sci 1269

Submitted: August 19, 2017; Accepted: November 8, 2017

Proofs received from author(s): December 27, 2017 